\title{
ANALYSIS OF FACTORS INFLUENCING FINANCIAL LEVERAGE IN LITHUANIAN LISTED COMPANIES
}

\author{
Kaupelytė, D., Mscichauskas, D.
}

The goal of the paper is to identify factors influencing financial leverage in Lithuanian listed companies. The factors influencing financial leverage have been analyzed in theoretical and empirical literature although the authors haven't found this type of research done in Lithuania. The authors analyze the theories explaining financial leverage and factors influencing financial leverage. Survey data include 2008-2012 year financial statements of 30 firms listed on the NASDAQ OMX Vilnius stock exchange. The methods used in this paper include econometric and regression analysis. The research allowed the confirmation of financial constraints (specifically, working capital) and a firm's industry as factors influencing financial leverage. Financial constraints impel companies to have higher financial leverage, and firms in the same industry are predisposed to change their financial leverage accordingly.

Keywords: financial leverage; listed companies; factors influencing financial leverage JEL classification: $\mathrm{O} 16$

\section{Introduction}

Financial leverage is not only one of the determinants of a corporation's profit-earning potential but also a source of its risk. For example, as described by M. Z. Frank and V. K. Goyal (2003), debt is related to adverse selection (in the framework of the pecking order theory), financial leverage determines the cost of capital (market timing and tax/bankruptcy tradeoff theories), debt is related to risk and costs of bankruptcy (tax/ bankruptcy tradeoff and agency theories), can work as a means of management control (agency theory) but can discourage stakeholder co-investments (stakeholder co-investment theory).

That is why it is important to identify the factors that influence the financial leverage in a firm. This would help to forecast both a company's own respective characteristics and the respective characteristics of its competitors. Moreover, increased knowledge of the phenomena may be used to identify problematic areas. All of this would help to make adequate managerial decisions.

Results of the theoretical analysis show that some authors define financial leverage as the size of debt relative to equity in a firm's capital structure. An analogical definition of financial leverage could be found in N. Dwenger and V. Steiner (2009), M. Z. Frank and V. K. Goyal (2003), J. R. S. Ramalho and J. L. Silva (2006), R. Seppa (2008). There are a number of theories explaining financial leverage and the factors influencing it.

Some authors use the ratio of debt to assets (Baggs and Brander, 2005; Chen, 2003; Ezeoha, 2008; Faulkender and Mitchell, 2004; Frank and Goyal, 2003; Hovakimian, 2004; Kaya, 2011; MacKay and Phillips, 2005; Seppa, 2008). The authors choose in this research paper to use the debt to assets ratio as a measurement of financial leverage. 


\subsection{Financial leverage irrelevance framework}

The theory of financial leverage irrelevance was created by F. Modigliani and M. H. Miller in 1958 (Kumar, 2007). This theoretical framework is acknowledged by R. Kumar (2007), J. Baggs and J. A. Brander (2005), J. J. Chen (2003), A. S. Gill et al. (2012), R. Stretcher and S. Johnson (2011), T. S. Zaher (2010). The main idea is that a firm's value is not affected by its capital structure because it is determined only by the expected return of the assets owned by the firm assuming that there is no transaction cost, there are no tax subsidies on the payment of interest, the rate of interest of borrowing by individuals and corporations is the same. However, this theory does not explain why companies have specific and different financial leverages.

\subsection{Agency cost framework}

This theoretical framework is acknowledged by R. Kumar (2007), M. Z. Frank and V. K. Goyal (2003), A. S. Gill et al. (2012), A. Hovakimian (2004), J. R. S. Ramalho and J. L. Silva (2006), R. Stretcher and S. Johnson (2011), T. S. Zaher (2010). The framework was adapted to capital structure decisions by M. C. Jensen and W. H. Meckling in 1976 (Kumar, 2007). The main idea is that financial leverage is determined by the agency costs. They arise from the fact that the company's owners delegate day-to-day decision making to managers. In this sense, management acts as agents for the company owners. But because of the conflicting goals between the two entities (shareholders seek firm value growth, dividends, etc. whereas the management seeks less work, more bonuses, etc.), certain costs arise. These are costs of monitoring the management, bonding costs (i.e. costs for the management when it tries to assure it serves the interests of the owners (Solomon and Solomon, 2004), residual losses. In this context, debt serves as a tool to discipline the management because it has to be paid back or it would lead to bankruptcy.

\subsection{Asymmetric information signaling framework}

This theoretical framework is acknowledged by R. Kumar (2007), J. J. Chen (2003), A. S. Gill et al. (2012), A. Hovakimian (2004), R. Stretcher and S. Johnson (2011), T. S. Zaher (2010). The research in this area was initiated by work of S. Ross and work of H. Leland and D. Pyle in 1977 (Kumar, 2007). The main idea is that leverage is determined by the costs arising from information asymmetry between the providers and beneficiaries of different kinds of funds (equity, debt). These costs are the required returns on types of funds and their level is inversely related to the level of knowledge about the company. On the other hand, managers may want to take advantage of information asymmetry and use leverage to signal certain firm prospects (Chen, 2003).

\subsection{Pecking order framework}

This theoretical framework is acknowledged by R. Kumar (2007), J. Baggs and J. A. Brandar (2005), J. J. Chen (2003), M. Z. Frank and V. K. Goyal (2003, 2009), A. Hovakimian (2004), H. D. Kaya (2011), G. Löffler and A. Maurer (2009), J. R. S. Ramalho and J. L. Silva (2006), R. Seppa (2008), R. Stretcher and S. Johnson (2011). The research in 
this area was initiated by work of S. C. Myers and N. S. Majluf in 1984 (Kumar, 2007). The main idea is that the capital structure is determined by the availability of funds for which there is a higher preference. Traditionally, it is thought that when funds are needed, firstly, internal financing (retained earnings) is being used and when there is not enough of it, external financing is chosen (but debt is preferred to equity).

\subsection{Static trade-off framework}

This theoretical framework is acknowledged by R. Kumar (2007), J. Baggs and J. A. Brandar (2005), J. J. Chen (2003), M. Faulkender and A. Mitchell (2004), M. Z. Frank and V. K. Goyal (2003), A. S. Gill, H. S. Mand, S. P. Sharma and N. Mathur (2012), A. Hovakimian (2004), H. D. Kaya (2011), G. Löffler and A. Maurer (2009), J. R. S. Ramalho and J. L. Silva (2006), R. Seppa (2008), R. Stretcher and S. Johnson (2011). The research in this area was also initiated by work of S. C. Myers and N. S. Majluf in 1984 (Kumar, 2007). The main idea is that capital structure is determined by the optimal level of debt. It is reached by making a trade-off between the level of financial distress/bankruptcy cost and tax shields (savings on corporate tax) related to debt. The former arises because of the fact that, as mentioned, debt has to be paid back and the latter because of the fact that interest payments are tax deductible.

\subsection{Stakeholder co-investment framework}

This theoretical framework is acknowledged by M. Z. Frank and V. K. Goyal (2003a). The origins of this theory can be traced to such works as by S. Titman in 1984. The main idea is that capital structure is determined by the firm's need for co-investment by its stakeholders. Stakeholders are understood as those who have an interest in the continued existence of the company (e.g. employees). They are believed to be more eager to make their investments if the firm is less leveraged.

\subsection{Transaction cost framework}

This theoretical framework is acknowledged by R. Kumar (2007). The research in this area was initiated by work of O. E. Williamson in 1988. The main idea is that the capital structure is determined by the management's aim to have the least costly transactions. The framework assumes bounded rationality ("behavior that was intentionally rational but only limitedly so" (Solomon and Solomon, 2004, p. 22) and opportunism (the tendency to take any opportunity to further one's own interests (Solomon and Solomon, 2004)). According to J. Solomon and A. Solomon (2004), the transaction cost theory can be considered to deal with the same issues as the agency cost theory, just from a different point of view.

\subsection{Target leverage (mean reversion) framework}

This framework is acknowledged by R. Kumar (2007), R. Stretcher and S. Johnson (2011). The research in this area was initiated by work of E. O. Fischer et al. in 1989 (Kumar, 2007). The main idea is that the capital structure is determined by what is perceived as optimal. Firms identify the target leverage range based on benefits and costs of debt and, when the actual leverage gets outside that range, action is taken to get it inside. 


\subsection{Legal environment framework}

The research in this area was initiated by work of R. La Porta, F. Lopez-de-Silanes, A. Shleifer and R. Vishny in 1997. The main idea is that the capital structure is determined by the legal environment in which a company is operating. For example, the degree of investor and creditor protection influences the size of appropriate markets and, accordingly, the opportunities of firms to accumulate funds through debt or equity.

\subsection{Market timing framework}

The theoretical framework is acknowledged by J. Baggs and J. A. Brander (2005), M. Z. Frank and V. K. Goyal (2003a), H. D. Kaya (2011), G. Löffler and A. Maurer (2009), R. Seppa (2008). The research in this area was initiated by the work of M. Baker and J. Wurgler in 2002 (Baggs and Brander, 2005). The main idea is that the capital structure is determined by the costs related to raising funds through debt and equity markets. The choice of funding depends on which source is considered cheap at a certain time.

Financial leverage may be influenced by various subsets of the identified determinants (and even those that are not recognized in the mentioned theories). Whenever they are in conflict, it may be a question of which determinant has the greater influence and financial leverage may as well be a result of a compromise between them.

The factors influencing financial leverage and most commonly identified in the empirical research are:

- firm size (Kurmar, 2007; Ezeoha, 2008; Frank and Goyal, 2003a; Ramalho and Silva, 2006; Seppa, 2008),

- $\quad$ profitability (Kumar, 2007; Chen, 2003; Gill et al., 2012; Shaher, 2012; Ramalho and Silva, 2006), growth (Gill et al., 2012; Ramalho and Silva, 2006; Chen, 2003),

- $\quad$ assets (Frank and Goyal, 2003a; Chen, 2003; Gill et al., 2012),

- taxes (Dwenger and Steiner, 2009; Frank and Goyal, 2003a; Gill et al., 2012),

- financial constraints (Frank and Goyal, 2003a; Ramalho and Silva, 2006; Shaher, 2012).

Financial leverage is not only one of the determinants of a corporation's profit-earning potential but also a source of its risk. For example, as described by M. Z. Frank and V. K. Goyal (2003a), debt is related to adverse selection (in the framework of the pecking order theory), financial leverage determines the cost of capital (market timing and tax/bankruptcy tradeoff theories), debt is related to risk and costs of bankruptcy (tax/ bankruptcy tradeoff and agency theories), can work as a means of management control (agency theory) but can discourage stakeholder co-investments (stakeholder co-investment theory).

Therefore it is important to identify factors that influence the financial leverage in a firm. This would help to forecast both a company's own respective characteristics and the respective characteristics of its competitors. Moreover, increased knowledge of the phenomena may be used to identify problematic areas. All of this would help to make adequate managerial decisions. Various frameworks were developed and numerous research in the area over various periods and in various countries has been done. Although to the authors' knowledge, the factors of financial leverage have never before been analyzed for Lithuanian listed companies. 
Therefore, the goal of the paper is to identify the factors and their impact on the financial leverage in Lithuanian listed companies.

The research question raised in this paper is what are the factors of financial leverage influencing financial leverage in listed companies in Lithuania?

Research methods and sources: The research was done utilizing the theoretical analysis of academic material and scientific articles, econometric, and regression analysis.

The following hypotheses are raised:

H1: Financial leverage in Lithuanian listed companies is determined by firm size, profitability, growth, assets, financial constraints and industry.

Hypothesis 2: There are differences between the relationships of financial leverage and some factors in Lithuania and in other countries.

\section{Methods}

Based on the literature overview, certain potential factors will be tested: firm size, profitability, growth, assets, financial constraints, industry. It will be tested whether these factors have a significant relationship with financial leverage. It should be noted that the relationship between financial leverage and the potential factors cannot be directly observed either. In this paper, what is common, a statistical/mathematical method econometrical, regression analysis - has been used.

Collection of data. The data was collected from the 2008-2012 year financial statements of 30 firms listed on the NASDAQ OMX Vilnius stock exchange (using the NASDAQ OMX Baltic website and other sources for additional information). The sample excludes 3 financial sector companies as their capital structure may be too different from the rest of the firms (Hovakimian, 2004). So the representation will be $91 \%$.

Variables. For estimation of financial leverage, the ratio of debt to total capital (sum of debt and equity) will be used:

$$
F L=D /(D+E)
$$

where $F L$ - financial leverage; $D$ - book value of debt (sum of long-term debt and shortterm debt); $E$ - book value of equity.

Firm size can be measured in two ways: as a natural logarithm of sales and of assets

$$
\begin{aligned}
& F S_{s}=\operatorname{Ln} S \\
& F S_{a}=\operatorname{Ln} A
\end{aligned}
$$

where $F S a$ - firm size (related to the sales dimension); FSa - firm size (related to the assets dimension); $S$ - sales; $A$ - assets.

Profitability will be measured as a ratio of earnings before interest, taxes, depreciation and amortization to total assets.

$$
\Pi=E B I T D A / A
$$

where $\Pi$ - profitability, EBITDA - earnings before interest, taxes, depreciation and amortization, $A$ - total assets.

Relating growth to the already discussed measurement for size, two measurements of firm growth will be used: relative change of firm size related to the sales and to the 
assets dimensions. Years will be used as periods of change as is common in financial calculations.

$$
\begin{aligned}
& G_{S}=\left(F S_{s t}-F S_{s t-1}\right) / F S_{s t-1} \\
& G_{A}=\left(F S_{a t}-F S_{a t-1}\right) / F S_{a t-1}
\end{aligned}
$$

where $G S$ - growth (related to the sales dimension); FSS - firm size (related to the sales dimension); $\mathrm{t}$ - index for year; $G A$ - growth (related to the assets dimension); FSa - firm size (related to the assets dimension).

The proxy for potential growth will be defined as a ratio of sales growth to asset growth.

$$
P G=\left(S_{t}-S_{t-1}\right) /\left(A_{t}-A_{t-1}\right)
$$

where $P G$ - potential growth; $S$-sales; $t$ - index for year; $A$ - total assets.

Tangibility will be measured according to the formula:

$$
T=(P P E+I) / A
$$

where $T$ - tangibility, $P P E$ - property, plant and equipment, $I$ - inventories, $A$ - assets.

As noted by J. J. Chen (2003), the most important element of non-debt tax shields is the depreciation. The variable to measure tax shield effects, used in the respective study, was the ratio of depreciation and amortization to total assets. The same variable will be used in this study:

$$
N D T S=D A / A
$$

where NDTS - non-debt tax shield; $D A$ - depreciation and amortization; $A$ - total assets.

The variables for financial constraints will be defined as in formulas:

$$
\begin{aligned}
& Z_{u}=(3.3 E B T+S+1.4 R E+1.2 *(C A-C L)) / A \\
& D P=1(\text { if } A D P>0) \text { or } D P=0(\text { if } A D P=0) \\
& G L R=C A / C L \\
& A L R=C / C A \\
& W C R=W C / A
\end{aligned}
$$

where $Z u$ - unleveraged Altman's Z-Score (Altman, 1968) ; EBT - earnings before taxes; $R E$ - retained earnings; $C A$ - current assets; $C L$ - current liabilities; $A$ - assets; $D P$ - dummy variable for dividend payment; $A D P$ - amount of dividends paid; GLR - general liquidity ratio; $A L R$ - absolute liquidity ratio; $C$ - cash; $W C R$ - working capital ratio; $W C$ - working capital.

Industry. The measure used by M. Z. Frank and V. K. Goyal (2003a) in this case was the median industry financial leverage. It is reasonable to think that if belonging to a certain industry has an effect on financial leverage, there should be some relationship between the general changing of these measures in that industry and in any specific firm. That is why this variable will be used. However, M. Z. Frank and V. K. Goyal (2003a) group the companies according to SIC (Standard Industrial Classification) which is a classification system used in the USA. For Lithuanian firms, the ICB (Industry Classification Benchmark) is used and, as could be seen on NASDAQ OMX Baltic site, there are 10 industries: 0001 Oil \& Gas; 1000 Basic Materials; 2000 Industrials; 3000 Consumer 
Goods; 4000 Health Care; 5000 Consumer Services; 6000 Telecommunications; 7000 Utilities; 8000 Financials; 9000 Technology.

Econometric analysis. Firstly, a variable selection process will be carried out. The variables will be tested for multicolllinearity. If pairs of independent variables were found to have a strong correlation, then the variables with the weakest correlation with the independent variable would be taken out until there were no more strong correlations between dependent variables. A correlation is considered strong if the correlation coefficient is -0.7 or less or if it is 0.7 or more (Saunders et al., 2003).

Then, taking all the remaining variables, a multiple linear regression analysis model will be used. The multiple model will be used because more than one independent variable will be tested (the model will be a simple linear regression if only one independent variable happened to remain after the mentioned variable selection).

$$
y=a+b_{1} x_{1}+b_{2} x_{2}+\ldots+b_{n} x_{n}+\varepsilon
$$

where $y$ - dependent variable, $a$ - constant; $b i$ - the regression coefficient corresponding to the ith independent variable $(\mathrm{i}=1,2, \ldots, \mathrm{n})$; $\mathrm{x} i$ - the ith independent variable $(i=1,2, \ldots, \mathrm{n}) ; n$ - the number of independent variables; $\varepsilon$ - error term.

The statistical significance of the regression equation will be tested with the F-statistic/p-value. As for regression coefficients, it will be checked by looking at the t-statistics/p-values. A 5\% confidence level will be used.

Limitations of the paper are choice of the research method and data period.

It should be noted that the relationship between financial leverage and the potential factors cannot be directly observed either. In this paper, what is common, a statistical/ mathematical method - econometrical, regression analysis - has been used to analyze it.

It is assumed that the factors can be adequately expressed in numbers and a statistical/mathematical relationship between these numbers says something about the real relationship. Moreover, it is assumed that if there is a relationship, it is the potential factors affecting financial leverage and not the other way around (i.e. the categorization of variables into one dependent and many independent is adequate).

The other important limitations of the regression analysis is that it only provides an approximation of an equation of a certain form and the regression coefficients are considered statistically significant under certain confidence levels.

Data period. As the data provided in the financial statements appear with a lag, the other limitation of this study is that it utilizes data from the years 2008-2012. It is assumed that no new relationship between financial leverage and the potential factors could be discovered taking into account data from different years and time lags. The latter limitation can be considered common in research (Frank and Goyal, 2003a)

\section{Results}

When looking at the variable correlation matrix, some strong correlations between dependent variables were found (correlation coefficients below -0.7 or above 0.7 ). Those were between $F S_{s}$ (firm size in the sales dimension) and $F S_{a}$ (firm size in the assets dimension), $\Pi$ (profitability) and $Z_{u}$ (unleveraged Z-score), FSa (firm size in the assets dimension) and MIFL (median industry financial leverage), WCR (working capital ratio) and $\mathrm{Zu}$ (unleveraged Z-score) (see table 1). 
Table 1 | Intercorrelation between financial leverage and variables with strong multicollinearity

\begin{tabular}{|l|c|c|c|c|c|c|c|}
\hline & $\mathbf{F L}$ & $\mathbf{F S}_{\mathbf{s}}$ & $\mathbf{F S}_{\mathbf{a}}$ & $\mathbf{\Pi}$ & $\mathbf{Z}_{\mathbf{u}}$ & $\mathbf{W C R}$ & $\mathbf{M I F L}$ \\
\hline $\mathbf{F L}$ & 1.000 & -0.407 & -0.388 & -0.374 & -0.484 & -0.700 & 0.446 \\
\hline $\mathbf{F S}_{\mathbf{s}}$ & -0.407 & 1.000 & 0.780 & 0.399 & 0.409 & 0.320 & -0.485 \\
\hline $\mathbf{F S}_{\mathbf{a}}$ & -0.388 & 0.780 & 1.000 & 0.182 & -0.011 & 0.079 & -0.708 \\
\hline $\mathbf{\Pi}$ & -0.374 & 0.399 & 0.182 & 1.000 & 0.726 & 0.465 & -0.156 \\
\hline $\mathbf{Z}_{\mathbf{u}}$ & -0.484 & 0.409 & -0.011 & 0.726 & 1.000 & 0.753 & 0.114 \\
\hline $\mathbf{W C R}$ & -0.700 & 0.320 & 0.079 & 0.465 & 0.753 & 1.000 & -0.039 \\
\hline $\mathbf{M I F L}$ & 0.446 & -0.485 & -0.708 & -0.156 & 0.114 & -0.039 & 1.000 \\
\hline
\end{tabular}

Source: authors

Of these variables, the ones with the weakest correlation with the independent variable $(F L)$ were taken out one by one: first, $\Pi$, then $F S_{a}$ and $Z_{u}$. Finally, 11 independent variables with not too much multicollinearity were left (see table 2).

Table 2 | Results of the variable selection procedure (remaining independent variables)

\begin{tabular}{|l|l|l|l|}
\hline Variable & \multicolumn{1}{|c|}{ Meaning } & Variable & \multicolumn{1}{c|}{ Meaning } \\
\hline FSs & Firm size (sales dimension) & DP & Dividend-paying \\
\hline Gs & Growth (sales dimension) & GLR & General liquidity ratio \\
\hline Ga & Growth (assets dimension) & ALR & Absolute liquidity ratio \\
\hline PG & Potential growth & WCR & Working capital ratio \\
\hline T & Tangibility & MIFL & Median industry financial leverage \\
\hline NDTS & Non-debt tax shield & & \\
\hline
\end{tabular}

Source: authors

Taking these variables, a linear regression model was constructed (see results of $1^{\text {st }}$ regression equation in Table 3). Even though it itself has been proven to be statistically significant $(\mathrm{F}$-statistic $=29.489, \mathrm{p}$-value $=0.000)$, the constant and some of the regression coefficients were found to be statistically insignificant (t-statistics not reaching the critical values, p-values higher than 0.05 ). 
Table 3 | 1st regression equation (constant $=-\mathbf{0 . 0 0 5}$ )

\begin{tabular}{|l|c|c|c|l|l|l|l|}
\hline Variable & $\mathbf{b}$ & $\mathbf{t}$ & $\mathbf{p}$ & Variable & $\mathbf{b}$ & $\mathbf{t}$ & $\mathbf{p}$ \\
\hline FS $_{\mathbf{s}}$ & 0.007 & 0.433 & 0.666 & $\mathbf{D P}$ & -0.046 & -1.351 & 0.179 \\
\hline $\mathbf{G}_{\mathbf{s}}$ & 0.320 & 1.505 & 0.135 & $\mathbf{G L R}$ & 0.004 & 0.415 & 0.679 \\
\hline $\mathbf{G}_{\mathbf{a}}$ & -0.077 & -0.377 & 0.706 & $\mathbf{A L R}$ & -0.058 & -1.343 & 0.182 \\
\hline PG & 0.000 & -0.210 & 0.834 & WCR & -0.821 & -11.194 & 0.000 \\
\hline T & -0.139 & -1.962 & 0.052 & MIFL & 0.871 & 6.758 & 0.000 \\
\hline NDTS & 1.482 & 3.266 & 0.001 & & & & \\
\hline
\end{tabular}

Source: authors; $b$ refers to the corresponding regression coefficient, $t$ - $t$-statistic, $p$ - $p$-value.

Accordingly, the variable with the highest corresponding p-value - PG (potential growth) - was removed. The same action was repeated until the final regression equation was received:

Table 4 | Final regression equation

\begin{tabular}{|l|c|c|c|l|c|c|c|}
\hline Variable & $\mathbf{b}$ & $\mathbf{t}$ & $\mathbf{p}$ & Variable & $\mathbf{b}$ & $\mathbf{T}$ & $\mathbf{p}$ \\
\hline NDTS & 1.062 & 2.738 & 0.007 & MIFL & 0.952 & 9.206 & 0.000 \\
\hline WCR & -0.772 & -14.316 & 0.000 & & & & \\
\hline
\end{tabular}

Source: authors; $b$ refers to the corresponding regression coefficient, $t$ - $t$-statistic, $p$ - $p$-value.

$$
F L=1.062 N D T S-0.772 W C R+0.952 M I F L+\varepsilon
$$

where FL - financial leverage; NDTS - non-debt tax shield; WCR - working capital ratio; MIFL - median industry financial leverage; $\varepsilon$ - error term.

Taxes. A positive relationship was found between financial leverage and the non-debt tax shield (a variable which is supposed to account for tax effects). It can be considered to be unsupported by the theoretical frameworks - in particular, the static trade off framework. That is because non-debt tax shields imply a reduction to taxable profit and one may expect a lesser need for financial leverage in this area. This can be also considered to be in conflict with the reviewed research, in particular, findings of N. Dwenger and V. Steiner (2009), M. Z. Frank and V. K. Goyal (2003a) and A. S. Gill, H. S. Mand, S. P. Sharma and N. Mathur (2012). In particular, it is in conflict with the research of N. Dwenger and V. Steiner (2009), M. Z. Frank and V. K. Goyal (2003a): according to them, financial leverage is lower for firms that benefit from other forms of tax shields.

Financial constraints. A negative relationship was discovered between financial leverage and the working capital ratio. This is the remaining variable, intended to account for financial constraints. This may be considered unsupported by the theoretical frameworks - the static trade-off framework in particular as financial constraints imply financial 
distress. The findings are also in conflict with the findings in the reviewed research. T. A. Shaher (2012) has found a positive relationship between financial leverage and working capital.

Industry. A positive relationship has been found between a firm's financial leverage and the median financial leverage of its industry. It is a variable, intended to account for the industry factor. This factor can be considered confirmed (see table 4). As already mentioned, this can be explained by similar forces affecting the companies in the same industry (Frank and Goyal, 2003a). And, while it cannot really be associated with any theoretical frameworks, it is in line with the findings of M. Z. Frank and V. K. Goyal (2003a), P. MacKay and G. M. Phillips (2005). In particular, it supports the findings of M. Z. Frank and V. K. Goyal (2003a) as they used the same variable to account for industry.

Table 5 | Results of the theoretical test of the discovered relationships between financial leverage and variables, representing certain factors

\begin{tabular}{|l|l|l|}
\hline Factor & Confirmation & \multicolumn{1}{|c|}{ Commentary } \\
\hline Taxes & No & $\begin{array}{l}\text { No clear explanation for the discovered respective } \\
\text { relationship could be found. }\end{array}$ \\
\hline Financial constraints & Yes & $\begin{array}{l}\text { The discovered respective relationships could be } \\
\text { explained by the idea that debt is used as a means to } \\
\text { cover liabilities. }\end{array}$ \\
\hline Industry & Yes & $\begin{array}{l}\text { The discovered respective relationship could be } \\
\text { explained by similar forces affecting the firms in the } \\
\text { same industry and is in line with the findings in the } \\
\text { overviewed research. }\end{array}$ \\
\hline
\end{tabular}

Source: authors

Some differences in the relationships discovered in Lithuania and in other countries could be found (see table 6). The financial constraints' factor seems to be affecting financial leverage in an opposite manner. However, when industry is considered, the affect seems to be congruent.

Financial constraints. Financial constraints, when measured by the working capital ratio, were found to have a positive statistical relationship with financial leverage. This could be said to imply that firmer financial constraints provide an incentive to companies to take up more debt which consequentially raises their financial leverage.

On the other hand, in the USA (Frank and Goyal, 2003a), Portugal (Ramalho and Silva, 2006) and Jordan (Shaher, 2012) the relationship is negative. This could be explained by a different, perhaps more forward-looking disposition not to take up debt in the face of financial constraints as that would just lead to more financial distress.

Industry. The median industry financial leverage (the variable to account for the industry factor) was found to have a positive statistical relationship with financial leverage. A different relationship was not found but the same one was found in research done in the USA (Frank and Goyal, 2003a). This seems to imply that the financial leverage of companies in the same industry is affected by the forces of the industry in the same way both in Lithuania and in the USA. 
Table 6 | Results of the comparisons of discovered relationships in Lithuania and in other countries

\begin{tabular}{|l|c|l|}
\hline Factor & Differences & \multicolumn{1}{|c|}{ Countries in which differences were found } \\
\hline $\begin{array}{l}\text { Financial } \\
\text { constraints }\end{array}$ & Yes & $\begin{array}{l}\text { USA (Frank and Goyal, 2003a) } \\
\text { Portugal (Ramalho and Silva, 2006) } \\
\text { Jordan (Shaher, 2012) }\end{array}$ \\
\hline Industry & No & - \\
\hline
\end{tabular}

Source: authors

Considering the findings of the previous stages of research, H1 cannot be fully confirmed. Financial leverage in Lithuanian listed companies was not confirmed to be affected by firm size, profitability, firm growth, firm assets, and taxes. Not all variables, representing respective factors, could be tested (because of multicollinearity) and not all factors were confirmed by the regression/significance analysis and theoretical test. But it can be considered to be affected by firm financial constraints and its industry.

$\mathrm{H} 2$ can be confirmed. Some differences were definitely found between the relationships between financial leverage and its factors in Lithuania and in the USA, Portugal and Jordan.

\section{Conclusions}

The main results of the empirical study and the limitations for their application are as follows. Financial leverage in Lithuanian listed companies was not confirmed to be affected by firm size, profitability, firm growth, firm assets, and taxes. But it can be considered to be affected by financial constraints and industry. Financial constraints (specifically, the smallness of the working capital) seem to impel companies to have higher financial leverage, and firms in the same industry seem to be predisposed to change their financial leverage in the same direction.

Some differences could be considered found between the relationships of financial leverage and some factors in Lithuania and in other countries. Specifically, financial constraints can be said to have an opposite relationship with financial leverage in the USA, Portugal and Jordan.

The limitations for the applicability are mainly related to the following facts. The financial sector companies were not taken into account. Many factors could not be confirmed due to multicollinearity and statistical insignificance of some variables. And, of the remaining ones, only those, for which a clear theoretical explanation was found, were confirmed. The comparison with other countries are limited because of different methods.

Taking into account the limitations of this study, the main possible future directions of research in this area could be the following. A larger data set (more years, more companies, including the financial sector) could be used. Time lags could be taken into account. The study could be done with other methods and applying different understandings of financial leverage and separate factors, supplemented with a survey for the managers. 
As far as comparison with other countries is concerned, an analogical method could be applied for analogical data of other countries to achieve greater comparability. If financial leverage is confirmed to be affected by industry, it may be investigated what specific elements of the industry affects it.

\section{References}

Altman, E. (1968). Financial ratios, discriminant analysis and the prediction of corporate bankruptcy, Journal of Finance 23(4), 589-609.

Baggs, J., \& Brander, J. A. (2005). Trade Liberalization, Profitability, and Financial Leverage. Statistics Canada Catalogue No. 11F0019MIE No. 256. 32 pp. Retrieved January 3, 2016 from http://dspace.cigilibrary.org/jspui/bitstream/123456789/589/1/Trade\%20 Liberalization\%20Profitability\%20and\%20Financial\%20Leverage.pdf?1.

Chen, J. J. (2003). Determinants of capital structure of Chinese-listed companies. Journal of Business Research, 57(12), 1341-1351.

Dwenger, N., \& Steiner, V. (2009). Financial leverage and corporate taxation: Evidence from German corporate tax return data. Arqus-Diskussionsbeiträge zur quantitativen Steuerlehre, 61. Retrieved January 5, 2016 from http://www.econstor.eu/dspace/bitstr eam/10419/30840/1/608204382.pdf.

Ezeoha, A. E. (2008). Firm size and corporate financial-leverage choice in a developing economy. Evidence from Nigeria. The Journal of Risk Finance, 9(4), 351-364.

Frank, M. Z., \& Goyal, V. K. (2003). Testing the pecking order theory of capital structure. Journal of Financial Economics, 67(2), 217-248.

Frank, M. Z., \& Goyal, V. K. (2009). Capital structure decisions: which factors are reliably important? Financial Management, 38(1), 1-37.

Gill, A. S., Mand, H. S., Sharma S. P., \& Mathur, N. (2012). Factors that Influence Financial Leverage of Small Business Firms in India. International Journal of Economics and Finance, 4(3), 33-45.

Hovakimian, A. (2004). The Role of Target Leverage in Security Issues and Repurchases. The Journal of Business, 77(4), 1041-1072.

Kaya, H. D. (2011). Syndicated bank loans and capital structure. Managerial Finance, 37(8), 697-714.

Kumar, R. (2007). Determinants of Firm's Financial Leverage: A Critical Review. Social Science Research Network. 45 pp. Retrieved January 30, 2016 from http://papers.ssrn.com/sol3/ Delivery.cfm/SSRN_ID1080883_code923423.pdf?abstractid=1080883\&mirid=3.

Löffler, G., \& Maurer, A. (2009). Incorporating the dynamics of leverage into default prediction. SFB 649 discussion paper, No. 2009,024. 24pp. Retrieved February 15, 2016 from http://www.econstor.eu/bitstream/10419/25340/1/598740201.PDF.

Mackay, P., \& Phillips, G. M. (2005). How Does Industry Affect Firm Financial Structure? The Review of Financial Studies, 18(4), 1433-1466.

Ramalho, J. R. S., \& Silva, J. L. (2006). A Two-Part Fractional Regression Model for the Financial Leverage Decisions of Micro, Small, Medium and Large Firms. Quantitative Finance, 9(5), 621-636.

Saunders, M. N. K., Lewis, P., \& Thornhill, A. (2003). Research Methods for Business Students, 3rd Edition, New York: Prentice Hall.

Shaher, T. A. (2012). The Impact of Determinants of Leverage on Capital Structure of Service Companies in Jordan. International Research Journal of Finance and Economics, 96, 6-14. 
Seppa, R. (2008). Capital structure decisions: Research in Estonian non-financial companies. Baltic Journal of Management, 3(1), 55-70.

Solomon, J., \& Solomon, A. (2004). Corporate Governance and Accountability. $1^{\text {st }}$ Edition, John Wiley \& Sons.

Stretcher, R., \& Johnson, S. (2011). Capital structure: professional management guidance. Managerial Finance, 37(8),788-804.

Zaher, T. S. (2010). Performance of debt free firms. Managerial Finance, 36(6), 491-501.

\section{Authors}

\section{Dalia Kaupelytė, PhD}

Assoc. Prof. Vytautas Magnus University, Finance Department

S. Daukanto 28, Kaunas, Lithuania

d.kaupelyte@evf.vdu.It

\section{Domas Mscichauskas}

\section{Master of Economics}

Vytautas Magnus University, Finance Department

S. Daukanto 28, Kaunas, Lithuania

domas.mscichauskas@gmail.com 